An Adapt ed Met hod for Remrving Change Det ecti on Errors due to Poi nt ing Di rection Shifts of a Sat el Iite Sensor

\begin{tabular}{|c|c|}
\hline 著者 & JEONG Jong Hyeok, TAKAG Masat aka \\
\hline $\begin{array}{l}\text { jour nal or } \\
\text { publ i cat i on } \mathrm{title}\end{array}$ & 写真測量とリモートセンシング \\
\hline vol une & 45 \\
\hline number & 2 \\
\hline page $r$ ange & $16-23$ \\
\hline year & 2006- 05- 01 \\
\hline 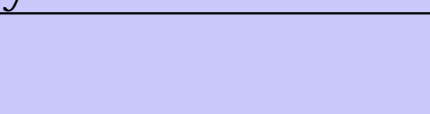 & $\begin{array}{l}\text { 人工衛星センサーにおげホポインティングの変動に } \\
\text { 伴う変化抽出誤差の低減法 }\end{array}$ \\
\hline URL & ht t p: //hdl . handl e. net /10173/647 \\
\hline
\end{tabular}




\title{
An Adapted Method for Removing Change Detection Errors due to Pointing Direction Shifts of a Satellite Sensor
}

\section{人工衛星センサーにおけるポインティングの変動に伴う変化抽出誤差の低減法}

\author{
鄭 鍾 赫*・高木 方隆* \\ Jong Hyeok JEONG and Masataka TAKAGI
}

\begin{abstract}
Geometrically corrected time series satellite images are often used for landcover change detections. The change detections are carried out under the assumption that pixel boundaries of geometrically corrected time series satellite images cover the same location. However that assumption can be wrong when shifts in the pointing direction of a satellite sensor occur. Currently, although the influence of misregistration on landcover change detection has been investigated, there have been few researchs on the influence of pointing direction shifts of a satellite sensor. In this study, a simple method for reducing the effects of pointing direction shifts of a satellite sensor is proposed: the classification of two ASTER images was carried out using the spectral mixture analysis, the two classification results are resampled into a geometrically fixed grid, and then the change detection of the two ASTER images was carried out by comparing the resampled classification results of the two images. The proposed method showed high performance in discriminating between changed areas and unchanged areas by removing the influence of the pointing direction shifts of a satellite sensor.
\end{abstract}

和文要旨：時系列リモートセンシングデータは，土地 被覆変化抽出のためによく使われている。この土地被 覆変化抽出は，リモートセンシングデータのピクセル が同じ場所をポインティングしているという前提で行 われている。しかし実際には，時系列データのポイン ティング位置がずれている。現在，幾何補正の誤差に よる土地被覆変化抽出への影響は研究されているが, ポインティングのずれによる土地被覆変化抽出への影 響は，あまり研究されてない。そこで，本研究は，ポ インティングのずれによる影響を少なくする手法を提 案する。そのとき，まずリモ一トセンシングデー夕は， サブピクセルの精度での幾何変換式を導く必要があ る。そして，ある空間に固定されたグリッドを用意し， その各グリッドに分類結果を再配列させる。再配列は, 空間に固定されたグリッドとリモートセンシングデー タのピクセル境界とをオーバーレイさせ, 面積の比例

*高知工科大学 社会システム工学科

Departmento of Infrastructure Systems Engineering Kochi University of Technology

高知県香美郡土佐山田町宮/ロ185

「写真測量とリモートセンシング」VOL. 45, NO. 2, 2006
配分にしたがって行う。この再配列に捛いては，ピク セル単位でカテゴライズされた分類結果であっても， 結果的にミクセルとして表現されるため, 始めからミ クセル分解された分類手法を用いることが望ましい。 したがって空間に固定されたグリッドへの再配列に よって，ポインティング位置のずれの影響を少なくす ることができる。シミュレーションによる評価を行っ たところ，ピクセル同士を直接比較する変化抽出法よ りも最大で $50 \%$ の精度向上が期待できた。

今回, 2 シーンの ASTER 画像を用いて提案する手 法によって土地被覆変化抽出を試みた。幾何変換式は, IKONOS 画像を用いてイメージマッチングにより平均 二乗鿁差 0.25 ピクセルの精度で導くことができた。ミ クセル解析により分類を行い, 固定されたグリッドに再 配列し, 変化抽出を実施した。その結果を画像化したと ころ,ピクセル同士を直接比較する変化抽出に比べて, ノイズの少ないシャープな結果を得ることができた。

\section{INTRODUCTION}

Change detection is one of the most important 


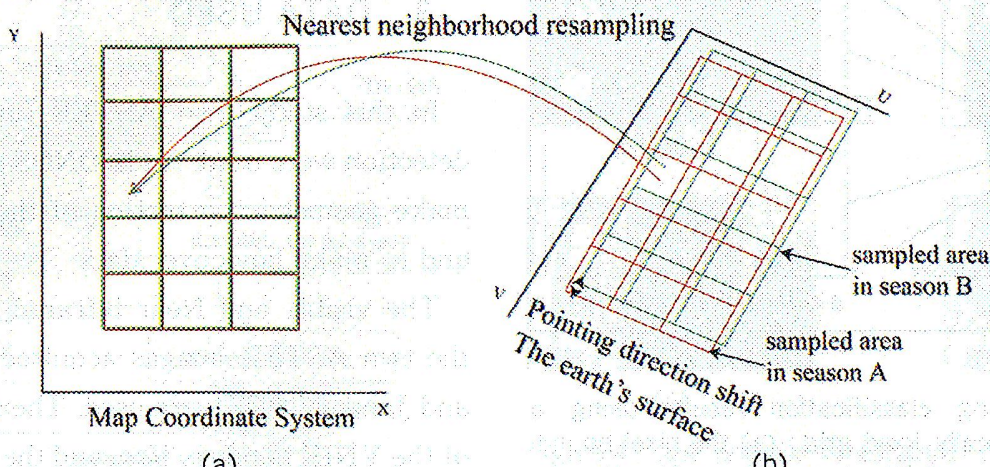

(a)

(b)

Figure 1 (a): The two geometrically corrected satellite images are pointing to the same location after geometric correction; (b): the two satellite images are actually covering slightly different areas.

analyses for solving problems, which relate to changing phenomena in the natural environment. Remotely sensed data is widely used for change detection because periodical and consistent data which cover wide areas are available.

When change detection is carried out, the remote sensor system and environmental system should be carefully considered. Poor understanding of the various parameters in the change detection process can lead to inaccurate change detection results (Jenson, 1996).

Geometric correction and resampling of satellite image are important research topic in change detection. In previous studies, Gong et al. (1992) used a median filter and adapted a grey scale mapping method to remove the change detection errors due to misregistration. The change detection errors due to misregistration means that the error of geometric correction depends on accuracy of GCPs or transformations. Townshend et al. (1992) investigated the impact of misregisration on change detection by shifting NDVI data that was derived from a MODIS data, and Stow (3999) proposed a misregistration compensation model to reduce the registration noise and to enhance landcover change.

Nearest neighbor resampling is a widely accepted in image resampling method for change detection because it does not modify the original pixel values of an image. However, the resampling method can cause errors in change detection, because incompletely overlaid areas might be compared when the coverage of each time series data is shifted. Figure 1 shows an example of such a situation: although the time series images are pointing the same location after their geometrical correction with nearest neighborhood resampling, the coverage of each image is pointing little different location by chang. ing satellite orbit and attitude. In this study, this situation is denoted as pointing direction shift.

The objectives of this study are to develop an adapted method for removing the change detection error due to the pointing direction shifts of a satellite sensor, and to evaluate the performance of the proposed method.

\section{METHODOLOGY}

The main reason for the change detection errors due to the pointing direction shifts of a satellite sensor is that the pixels of time series satellite images are covering slightly different areas. To minimize the error in comparing incompletely overlaid areas, the classification results of time series images should be transformed with subpixel accuracy. Then the pixels of the classification result are resampled into geometrically fixed grid data, after which the same coverage of the time series satellite image can be compared. Equation (1) describes the 


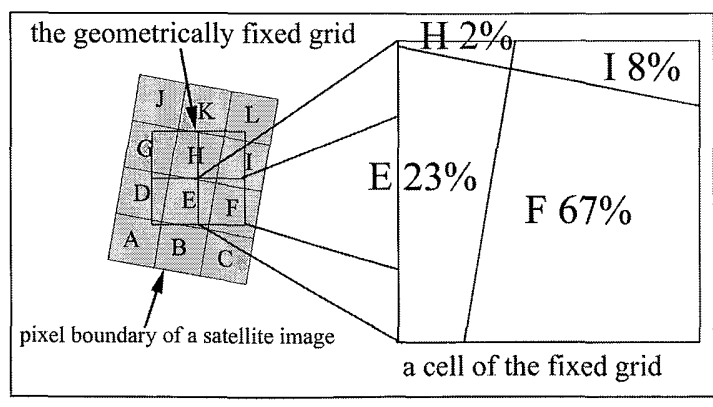

(a)

(b)

Figure 2 Resampling classification results using a geometrically fixed grid: (a) the pixel boundary of a satellite image overlaid with the geometrically fixed grid, (b) the existence ratio of each pixel in the sample cell of the grid is calculated.

resampling method: the existence ratio of pixels which overlaid on a grid cell were multiplied by their pixel value.

Grid cell value $=\sum_{j=0}^{M} R_{j} \times$ pixel value ${ }_{j}$

where $j$ is pixel order, $M$ is the total number of pixels, and $R$ is the existence ratio of each pixel which was overlaid on the grid cell.

Figure 2 shows how the value of geometrically fixed grid cell was calculated using proposed method: The source satellite image contains pixels which are named from A to L. A geometrically fixed grid is overlaid with the pixel boundary of a satellite image (figure $2-a$ ). To calculate the sample grid cell value, the existence ratio of the pixels H, I, $\mathrm{E}$ and $\mathrm{F}$ on the grid cell was calculated (figure 2-b). The pixels $\mathrm{H}, \mathrm{I}, \mathrm{E}$ and $\mathrm{F}$ take $2 \%, 8 \%, 23 \%$ and $67 \%$ in the grid cell respectively. The existence ratio of each pixel is multiplied by the pixel's value. Finally the summation of the multiplication results becomes the grid cell value.

The proposed method uses existence ratio (area ratio) as weight to interpolate a suitable value, while bilinear and cubic convolution resampling methods use distance as weight to interpolate a suitable value. Hence, the proposed method is based on physical meaning rather than the conventional interpolation method.

\section{DATA USED}

In this study, two ASTER images for change detection were used. An IKONOS scene was used to make geometric correction of the ASTER images and to make landcover data.

The visible and Near-infrared (VNIR) bands of the two ASTER images acquired in October 2001 and January 2002 were used. The spatial resolution of the VNIR bands is $15 \mathrm{~m}$, and the test area is $11 \mathrm{~km}$ by $11 \mathrm{~km}$ in Tosayamada, Kochi pref., Japan. The ASTER images used in this study are level 1B data, thus already system correction were applied to the data. Ordinary, the raw data of the ASTER images should be used for this study. However the level 1B data was used in this study.

The IKONOS image acquired in September 1999 consists of three visible bands and one near infrared band, and its spatial resolution is one meter by pan -sharpen processing. The IKONOS image covers $11 \mathrm{~km}$ by $11 \mathrm{~km}$.

\section{EVALUATION BY A SIMULATION}

\subsection{Simulation of pointing direction shifted data using a landcover map}

The purpose of this simulation is to understand the tendency of error produced according to the pointing direction shift. It is difficult to detect change detection error due to pointing direction shift using actual satellite image, because it is hard to separate the change detection error from land. cover change. Therefore it is necessary to make change detection in no change condition to understand the influence of pointing direction shift. If the landcover is homogeneous, the error in the change detection due to pointing direction shift may not affect much on the result. On the other hand, if there is many landcover boundaries exist, the change detection error can affect much on the result. The area of test site for the simulation is about $7.3 \mathrm{~km}$ by $7.3 \mathrm{~km}$. The boundary of each landcover clearly exists. 


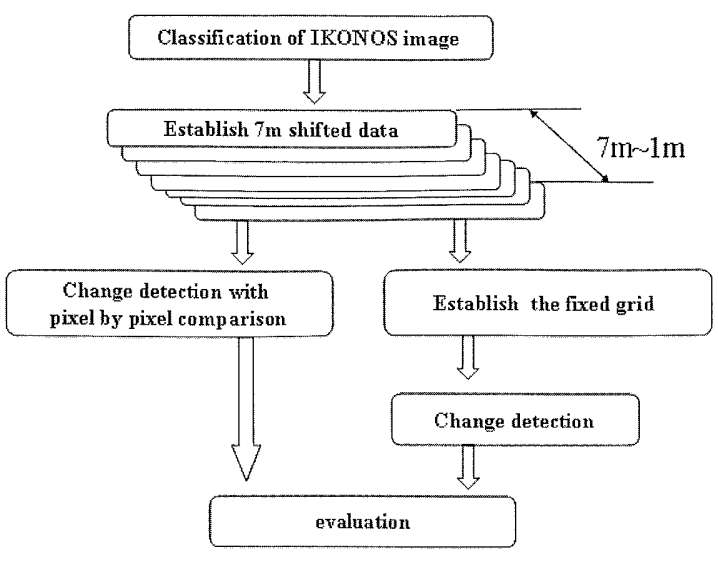

Figure 3 Simulation flow

Figure 3 shows the flow of the simulation : pointing direction shifted data were simulated, and then the change detection was performed using the pixel by pixel comparison method and the proposed method.

In this simulation, the spectral mixture analyses results of ASTER images were simulated. Virtual landcover can be used for the simulation. However, the actual landcover information derived from the IKONOS image was used in this study. The simulation was carried out under the assumption that the landcover information is $100 \%$ correct.

Figure 4 shows the process of generating pointing direction shifted data. Figure 4-a shows the test area in the IKONOS for the simulation. Figure 4-b shows the classification result of the IKONOS image classified by visual interpretation. The test area for the simulation was covered by water, vegetation and bare soil as endmember for spectral mixture analysis.

Figure $4^{-} \mathrm{C}$ shows that the pixel boundary of simulated ASTER image on the classification result was plotted onto the classification result with $15 \mathrm{~m}$ resolutions to simulate an ASTER image.

The landcover attribute of the simulated data was derived from the classification results: the existence areas of each landcover in a grid cell was counted, thus they became the existence ratio of each endmember (Figure $4-\mathrm{d}$ ). Then the pointing direction shifted data were established by moving

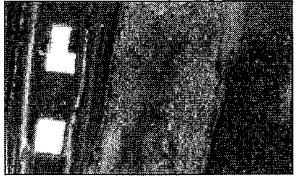

(a)

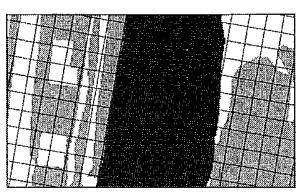

(c)

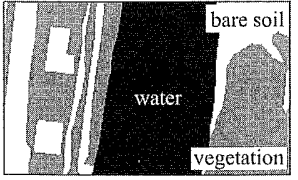

(b)

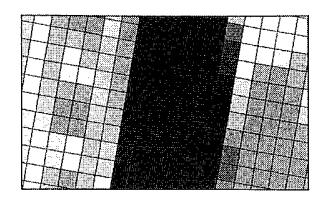

(d)
Figure 4 the process to establish data for the simulation: (a) the test area for simulation, (b) classification result of the IKONOS image by visual interpretation, (c) pixel boundary of simulated ASTER image on the classification result, (d) the area of each landcover is measured, then the values are assigned to the fixed grid cell as mixed proportion of endmem. ber.

the pixel boundary of a test image from one meter to seven meters with one meter interval.

\subsection{Change detection of the simulated data using the pixel by pixel comparison method}

Figure 5 shows an example of change detection shifted data using pixel by pixel comparison method. Figure 5-a and figure 5-b show one meter shifted data and seven meters shifted data. The two data were established on the figure 4-b. Pixel values in figure $5^{-}$a are different from pixel values in figure $5-b$ because the pixel boundary is shifted. The landcover attribute of data shifted zero meter is compared with data shifted one to seven meters.

\subsection{Change detection of the simulated data using the proposed method}

Figure 6 shows an example of the change detec-

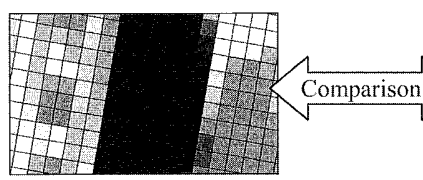

(a)

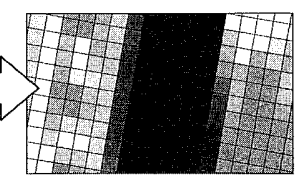

(b)
Figure 5 Change detection of the pointing direction shifted data using pixel by pixel comparison method: (a) Om shifted data, (b) $7 \mathrm{~m}$ shifted data. 


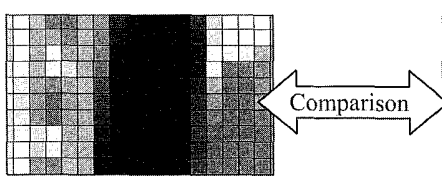

(a)

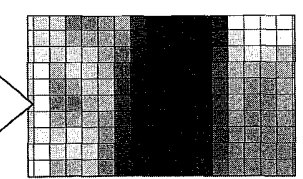

(b)
Figure 6 Change detection of the pointing direction shifted data using the proposed method: (a) the fixed grid of $0 \mathrm{~m}$-shifted data, (b) the fixed grid of $1 \mathrm{~m}$ to $7 \mathrm{~m}$-shifted data.

tions using the fixed grids; fixed grid data for pointing directions of zero to seven meters shifted data were generated. The landcover attributes of the simulated data were resampled into each fixed grid. A fixed grid overlaid on figure $5-a$ and $5-b$, then resampling of them was carried out using the proposed method. Figure $6^{-\mathrm{a}}$ and $6^{-\mathrm{b}}$ show the resampled zero meter shifted data and seven meters shifted data.

The change detections were performed by comparing the fixed grid of zero meters with the fixed grids of one to seven meters.

\subsection{Results}

The simulation was carried out under no change condition in landcover. Therefore, The degree in the change detection became the change detection error due to the pointing direction shifts. The change detection error was measured using Equation (2).

$E=\frac{\sum_{i=1}^{N} \sum_{j=1}^{M} \mid 0 m_{-} \text {shift }_{i j}-X m_{-} \text {shift }_{i j} \mid}{M \times N}$

where $E$ is the average of the change detection error, $i$ is pixel order, $N$ is the total number of pixels in the pixel boundary, $M$ is the total amount of the landcover, $j$ is the landcover, $0 m_{-}$shift is percentage of the existence ratio of landcover in the zero meter shifted data, and $X m_{-}$shift is percentage of the existence ratio of landcover in the $X$ meter shifted data. The $E$ describes that how much percent of a pixel contains change detection error in average. $0 \%$ of $E$ means no change, and $100 \%$ of $E$ means whole of a pixel changed.

Figure 7 shows the result of simulation. When 7 meters of a pixel shifted, the average of the change

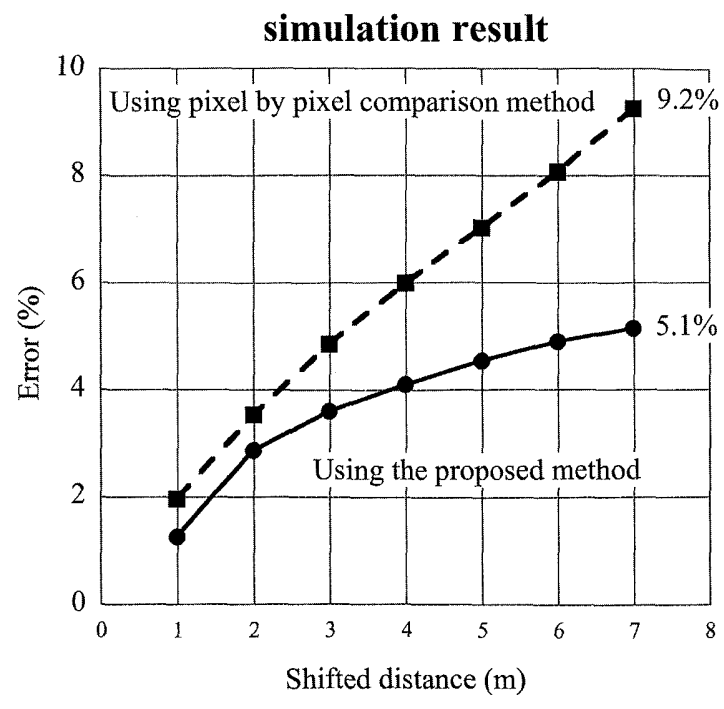

Figure 7 Comparison between the classification results of the pixel by pixel comparison and the proposed method

detection errors of the pixel by pixel comparison method and the proposed method generated approximately $9.2 \%$ and $5.1 \%$. The result shows that the proposed method can improve approximately half of the change detection error by the pixel by pixel comparison method. Although the proposed method is more efficient than the pixel by pixel comparison method, still $5.1 \%$ of change detection error is existed.

\section{A CASE STUDY USING TWO ASTER IMAGES ACQUIRED IN OCTOBER 2001 AND JANUARY 2002}

To evaluate the performance of the proposed method, the change detection between two ASTER images acquired in October 2001 and January 2002 was performed using both the pixel by pixel comparison method and the proposed method.

\subsection{Relative normalization}

Radiometric differences of time series satellite images can be greater than landcover change. To remove the radiometric difference of the two ASTER images, linear transforms of the two images were used; the transforms can be established by using fixed outputs and the average DNs 
of minimum and maximum inputs from pure sea water and unchangeable bare soil area.

\subsection{Spectral mixture analysis for landcover map- ping}

Almost classification methods represent major landcover in each pixel as classification results, but that may degrade the accuracy of classification when the result is resampled into a geometrically fixed grid. Therefore, linear spectral mixture analyses of the two ASTER images were carried out to derive the mixing proportions of endmembers. The linear mixture analysis is carried out under the assumption that the combination of the measured spectrum by a sensor is linear (Adams, et al., 1995). The proportional change of endmembers was examined to perform change detection. Water, bare soil (including urban surface) and vegetation were selected as endmembers, and the proportions of the three endmembers in each pixel were investigated. Ten pure pixels per endmember were taken from the normalized October scene. Normalized DNs of the pure pixels and existence ratio of endmembers from the training data were input to the Equation (3) in order to obtain the spectral signatures of $i$ th endmembers $(C)$.

Normalized__ $D N_{n}=\sum_{i=1}^{M} f_{i} C_{n, i}$

where $n$ is the band, $i$ is the endmember (1: water, 2: bare soil, 3 : vegetation), and $M$ is the last number of endmembers and $f$ is the existence ratio of $i$ th endmember.

Then conversely, the spectral signature of each endmember and DNs of the relatively normalized ASTER images were input to the equation 3 for unmixing the existence ratio of each endmember $(f)$ in a pixel. The spectral signatures of the endmemers were used for the mixture analysis of the two normalized ASTER scenes.

\subsection{Geometric transforms using IKONOS images and the proposed resampling method}

Geometric correction of time series satellite images is one of the most important processes in change detection. The geometric corrections of the two ASTER images were performed with the aim of achieving subpixel accuracy. Affine transform was used for the geometric corrections because the test area was small $(11 \mathrm{~km}$ by $11 \mathrm{~km})$ enough to be applied the transform.

To achieve subpixel accuracy, image matching between the two ASTER images and a geometrical. ly corrected IKONOS image was performed to obtain accurate ground control points. The IKONOS image was geometrically corrected by three dimensional Affine transform, and the RMS error of the geometric correction was less than one meter.

To align the ASTER images with the IKONOS image, Affine transform was carried out using GCPs which were obtained by manually, after which the image matching was performed to make the affine transformation more accurate. The similarity between a template and a target image was measured using image correlation (Equation 5).

$$
\operatorname{Corr}=\frac{\sum_{i=1}^{m} \sum_{j=1}^{n}\left[\left(A_{i j}-\bar{A}\right)\left(B_{i j}-\bar{B}\right)\right]}{\sqrt{\left[\sum_{i=1}^{m} \sum_{j=1}^{n}\left(A_{i j}-\bar{A}\right)^{2}\right]\left[\sum_{i=1}^{m} \sum_{j=1}^{n}\left(B_{i j}-\bar{B}\right)^{2}\right]}}
$$

where Corr is the correlation between a template image and a target image, $A$ is the array of a template image, $B$ is the array of a target image, $i$ represents rows, and $j$ represents columns.

For the image matching, five templates for the October image and four templates for the January image were used, and manmade objects in the test area were used for templates because they are not significantly affected by the seasonal change.

Template images from band 3 (VNIR) of the ASTER images are compared with target images from band 2 of the IKONOS image because their spectral responses are close to each other. Figure 8 shows an example of image matching carried out in this study: figure $8^{-} \mathrm{a}$ and $8^{-\mathrm{b}}$ are a target image from a ASTER image and a template image from the IKONOS image, respectively. The figure $8-\mathrm{a}$ 


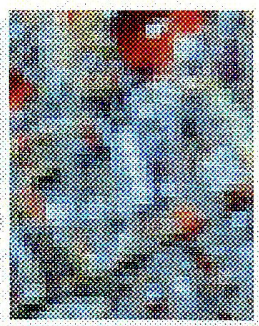

(blue : band 1, green: band 2 and red band3)

(a) Target inage from the ASTER

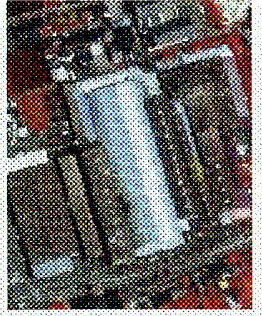

(blue: band2, green: band 3 and red: band4)

(b) Template image from the IKONOS

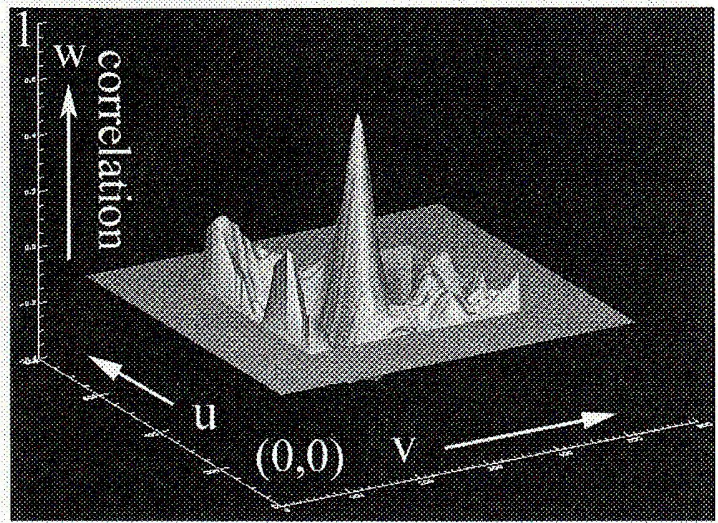

(c) Correlation image

Figure 8 An example of image matching between an target image from an ASTER image and a template image from the IKONOS image

and 8 b are false color image which are consist of visible green, visible red and infrared bands. After the image natching, correlation image (figure 8 c) could be obtained. In figure $8-\mathrm{c}, u$ axis is column, $v$ axis is row, and $v$ axis is correlation. All of the correlation images showed a peak of correlation. Almost correlations of image matchings were over 0.7, which implies good matching (Konecny, 2003).

Table 1 shows the RMS errors in the geometric correction of the two ASTER images. The results show that a maximum registration error of $2.34 \mathrm{~m}$ (0.16 pixel of the ASTER image) was occurred. The accuracy of the geometric correction was accept. able because it was less than one quarter of the ASTER's pixel size (Lillesand, 2000).

For the pixel by pixel comparison of the images, the results of spectral mixture analysis of the images were transformed by the established Affine transformation with $15 \mathrm{~m}$ interval nearest neighbor
Table 1 the RMS errors in the geometric correction of the two ASTER images (units: meter)

\begin{tabular}{|r|r|r|}
\hline October 2001 RMS error X & RMS error Y \\
\hline Januay 2002 . & 0.93 & 1.42 \\
\hline
\end{tabular}

resampling was performed, then change detection between the two ASTER data was carried out.

On the other hand, change detection was perfor: med using the proposed method: the transformed data were resamipled into the geometrically fixed grid using the proposed method. Finally the two resampled classification results into the fixed grid were compared each other.

\subsection{Change detection results}

It is difficult to recognize change detection error due to pointing direction shift in the change detection of the areas where covered by homogeneous

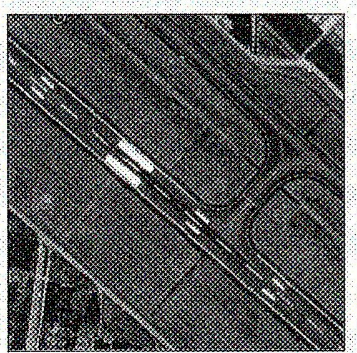

(a)

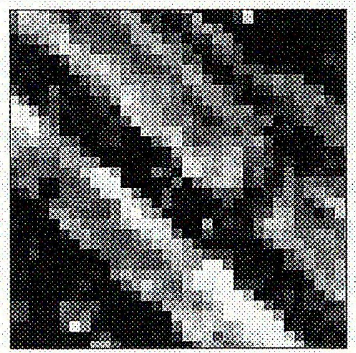

(c)

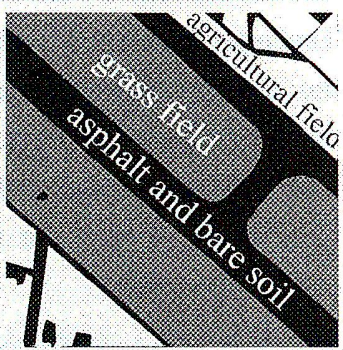

(b)

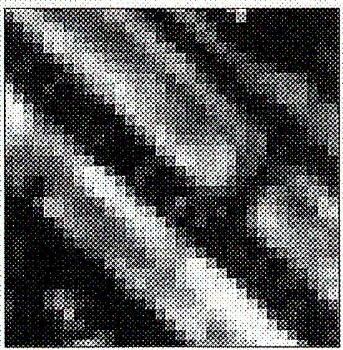

(d)
Figure 9 (a) the test area in the IKONOS image which has simple landcover, (b) the test area cov. ered by grass field, asphalt with painted areas and agricultural field, (c) the change detection result of the ASTER images by the pixel by pixel comparison method, (d) the change detection result of the ASTER using the proposed method 
landcover because the error is included into the change of landcover. Therefore, landing strip around Kochi airport, which has clear boundaries of landcovers, is shown as a result of the change detection (Figure 9-a). Figure 9-b shows landcover type on the selected area where is covered by unchangeable objects such like asphalt, painted area with white color, and changeable objects such like grass field and agriculture field. From October 2001 to January 2002, only the landcover of grass field changed.

Figure $9-\mathrm{c}$ and $9-\mathrm{d}$ show the change detection results by the two methods: the brightness of each pixel was expressed by the degree of landcover change. Thus, the brightest areas indicate the area in which the most landcover change occurred.

Figure $9-\mathrm{c}$ shows the result of change detection by the pixel by pixel comparison method. Some noises were shown along the boundary between landing strips and the grass field because incompletely overlaid areas were compared. Especially, there are more noises on the asphalt.

Figure 9-d shows the result of change detection by the proposed method. The result shows that more meaningful change detection result than the result by the pixel by pixel comparison method. The boundary between the changed area (grass fields) and unchanged area (landing strips) could be clearly discriminated.

As described in the simulation, pixel by pixel comparison method shows the tendency to generate more change than actual change. Also in the result of change detection using the ASTER images, the degree of landcover change in result of pixel by pixel comparison method seems more exaggerated than the result by the proposed method because it contains noises due to the pointing direction shift.

\section{CONCLUSIONS}

The present study pointed out the influence of pointing direction shifts on satellite sensor detection and the weak points of the nearest neighborhood resampling method on change detection. From this study following conclusions were arrived at:

1) An adapted method for removing the change detection error due to pointing direction shift of a satellite sensor was developed.

2 ) The performance of the adapted method was evaluated by comparing with the pixel by pixel comparison method: the adapted method showed a more meaningful change detection result.

The pointing direction shifts of satellite sensors can cause change detection errors, and should be considered in change detection.

（受付日2005.7.4, 受理日2006.3.10）

\section{REFERENCES}

Adams, J.B., D.E. Sabol, V. Kapos, R.A. Filho, D.A. Roberts, M.O. Smith, and A.R. Gillespie, 1995. Classification of multispectral images based on fractions of endmembers: Application to land cover change in the Brazilian Amazon, Remote Sensing of Environment, 52: pp.137-154.

Gong, P., Ledrew, E.F., and Miller, J.R., 1992, Registration-noise reduction in difference images for change detection. International Journal of Remote Sensing, 13, pp.773-779.

Jensen, J.R., 1996. Introductory Digital Image Processing: A Remote Sensing Perspective second Edition, Prentice Hall, p.468.

Konecny, G., 2003, Geoinformation, Taylor \& Francis, p.166.

Lillesand, T., Kiefer, R., 1994. Remote Sensing and Image Interpretation, $3^{\text {rd }}$ Edition, John Wiley and Sons, p.578.

Stow, D., 1999, Reducing misregistarion effects for pixel-level analysis of land-cover change, International Journal of Remote Sensing, 20, pp.24772483.

Townshend, J.R.G., Justice, C.O., Gurney, C., and McManus, J., 1992, The impact of misregistration on change detection. IEEE Transactions on Geoscience and Remote Sensing, 30, pp.1054-1060. 